\title{
Supporting Information: Solar steam generation integration into the ammonium bicarbonate recovery from liquid biomass digestate: process modeling and life cycle assessment
}

Joshua C. Centorcelli, ${ }^{1}$ Donata Drapanauskaite, ${ }^{1,2}$ Robert M. Handler ${ }^{3}$ and Jonas Baltrusaitis ${ }^{1, *}$

${ }^{1}$ Department of Chemical and Biomolecular Engineering, Lehigh University, B336 Iacocca Hall, 111 Research Drive, Bethlehem, Pennsylvania 18015, United States

${ }^{2}$ Lithuanian Research Centre for Agriculture and Forestry, Instituto al.1, LT-58344, Akademija, Kedainiai District, Lithuania

${ }^{3}$ Sustainable Futures Institute, Michigan Technological University, 1400 Townsend Drive, Houghton, MI 49931, United States

Number of pages 10

Number of Tables 5

*Corresponding author: job314@1ehigh.edu. Phone +1-610-758-6838 


\section{Economic analysis assumptions.}

-assume only one operator is required to monitor the whole process with 2 additional workers to account for sick time and time off with 5 operators we have 1.25 operators per shift

-The salary of each operator was 50,000 a year

-the employee benefits were $30 \%$

- Operating supervision was 10\% since engineers are already on site for operation of the biogas plant

-Maintenance was $1.5 \%$ of the total investment because the unit is relatively small

-A majority of maintenance cost was associated with materials rather than labor because of the fact that we expect that maintenance workers will already be on site for the biogas plant so maintenance workers will already be skilled at repair on most things (30/70 split favoring material over labor)

-General labor overhead was $45 \%$ due the plant being injunction with a biogas facility less overhead is required a biogas worker could supervise for fertilizer plant if necessary -sales and administration were $0 \%$ because the same sales team and administrative team could cover both the biogas and small fertilizer operation

-R\&D was $1 \%$ due to the unit being so small and a lot cost coming from the solar cycle which requires no $R \& D$

Table S1. Equipment and installed costs used in economic evaluation

\begin{tabular}{|c|c|c|c|}
\hline & $\begin{array}{l}\text { Equipment } \\
\text { cost }\end{array}$ & $\begin{array}{l}\text { Installed } \\
\text { cost }\end{array}$ & Aspen Icarus ID \\
\hline RAW-FEED & 6300 & 40500 & DCP CENTRIF \\
\hline HX2 & 10400 & 58400 & $\begin{array}{l}\text { DHE TEMA } \\
\text { EXCH }\end{array}$ \\
\hline DE-NH3-cond & 19000 & 89200 & $\begin{array}{l}\text { DHE TEMA } \\
\text { EXCH }\end{array}$ \\
\hline DE-NH3-cond acc & 12900 & 82400 & $\begin{array}{l}\text { DHT HORIZ } \\
\text { DRUM }\end{array}$ \\
\hline DE-NH3-reb & 44900 & 128900 & DRB U TUBE \\
\hline $\begin{array}{l}\text { DE-NH3-reflux } \\
\text { pump }\end{array}$ & 4600 & 32200 & DCP CENTRIF \\
\hline DE-NH3-tower & 254900 & 470700 & DTW TOWER \\
\hline HX1 & 138400 & 276100 & $\begin{array}{l}\text { DHE TEMA } \\
\text { EXCH }\end{array}$ \\
\hline CRYST & 113700 & 179100 & ECRYOSLO \\
\hline P3 & 4600 & 28700 & DCP CENTRIF \\
\hline B6 & 545800 & 700700 & DGC CENTRIF \\
\hline DECANTER & 231900 & 284500 & $\begin{array}{l}\text { ECT SOLID } \\
\text { BOWL }\end{array}$ \\
\hline P5 & 4600 & 26700 & DCP CENTRIF \\
\hline
\end{tabular}




\begin{tabular}{|l|l|r|r|l|}
\hline & E100 & 8500 & 53600 & $\begin{array}{l}\text { DHW TEMA } \\
\text { EXCH }\end{array}$ \\
\hline & DRYER1 & 10600 & 17400 & $\begin{array}{l}\text { ED ATMOS } \\
\text { TRAY }\end{array}$ \\
\hline & & & & \\
\hline SOLAR & vaporizer & 44200 & 139400 & $\begin{array}{l}\text { DHE TEMA } \\
\text { EXCH }\end{array}$ \\
\hline & PUMP1 & 23300 & 93400 & DCP CENTRIF \\
\hline & PUMP2 & 5300 & 33300 & DCP CENTRIF \\
\hline & & & & $\begin{array}{r}\text { Installed cost of } \\
\$ 170 / m^{2}{ }^{\prime}\end{array}$ \\
& Panels & 502894 & 718420 & $\begin{array}{r}\text { installation cost of } \\
30 \%\end{array}$ \\
\hline & EG Storage & 99000 & 110000 & $\begin{array}{r}\text { CAPCOST Turton } \\
\text { et al. }{ }^{2}\end{array}$ \\
\hline & Water storage & 42300 & 46500 & $\begin{array}{r}\text { CAPCOST Turton } \\
\text { et al. }{ }^{2}\end{array}$ \\
\hline
\end{tabular}

Table S2. Economic assumptions for full cash flow analysis

\begin{tabular}{|c|c|c|}
\hline Parameter & Value & Description \\
\hline \multicolumn{3}{|l|}{ General } \\
\hline Tax rate & $23 \%$ & Current corporate tax rate of $21 \%+2 \%$ state \\
\hline Investment Creep & $1.30 \%$ & \\
\hline First Year Creep & $3.00 \%$ & \\
\hline Discount Rate & $10 \%$ & Our investors rate of return \\
\hline \multicolumn{3}{|l|}{ Fixed Cost } \\
\hline Number of Operators & 6 & \\
\hline Wage & 50000 & \\
\hline Employee benefits & $30 \%$ & As a percentage of wage \\
\hline Supervision & $15 \%$ & salary compensation for engineer \\
\hline Cost of operating supplies & $5 \%$ & As percentage of wages \\
\hline Total maintenance & $1.50 \%$ & Of capital cost \\
\hline $\begin{array}{l}\text { Split of } \\
\text { maintenance(Material/Labor } \\
\text { ) }\end{array}$ & $\begin{array}{l}(70 / 30) \\
\%\end{array}$ & \\
\hline Overhead & $45 \%$ & of all labor costs \\
\hline technical support & $1 \%$ & of investment \\
\hline $\mathrm{R} \& \mathrm{D}$ & $1 \%$ & of investment \\
\hline Taxes & $1.5 \%$ & of investment \\
\hline Royalties & $\$ 0.00$ & Dollars per $1 \mathrm{~b}$ of product \\
\hline Depreciation & $8.33 \%$ & of capital investment \\
\hline
\end{tabular}




\begin{tabular}{|l|r|l|}
\hline Equipment Costs & & \\
\hline Misc Equipment & $10 \%$ & of total equipment post \\
\hline Field erected Equipment & $\$ 3,000$ & \\
\hline Field Materials & $5 \%$ & of the equipment cost \\
\hline Labor & $10 \%$ & of the the equipment costs \\
\hline Insulation & $10 \%$ & of the the equipment costs \\
\hline Supports and foundations & $10 \%$ & $\begin{array}{l}\text { of field erected equipment, field materials, labor, and } \\
\text { insulation }\end{array}$ \\
\hline Piping & $40 \%$ & $\begin{array}{l}\text { of all installed equipment(installed equipment = equip } \\
\text { cost plus all above) }\end{array}$ \\
\hline Instruments & $15 \%$ & of installed equipment \\
\hline Electrical & $7 \%$ & of installed equipment \\
\hline $\begin{array}{l}\text { Split of equipment } \\
\text { installation(\%M/\%L) }\end{array}$ & $(70 / 30)$ & \\
\hline Freight, QA, sales taxes & $\%$ & \\
\hline Contractor labor & $22 \%$ & of the material split \\
\hline & & afl engr equipment is um of all above \\
\hline building and structures & $3 \%$ & of all engr equipment \\
\hline Factored power & $1 \%$ & of all engr equipment + buildgs \\
\hline dismantling and rearranging & $2 \%$ & of all engr equipment + buildgs \\
\hline Site development & $2 \%$ & of all engr equipment + buildgs \\
\hline & & \\
\hline contingency & $10 \%$ & of all above \\
\hline Working conditions & $1 \%$ & of all above \\
\hline field indirects & $3 \%$ & of all above \\
\hline & & \\
\hline Inflation during first 2 years & $2 \%$ & \\
\hline
\end{tabular}




\section{Life cycle input data and key assumptions.}

Table S3 - LCA input data for $\mathrm{NH}_{4} \mathrm{HCO}_{3}$ production, based on 30,000 $\mathrm{kg}$ of liquid digestate treatment

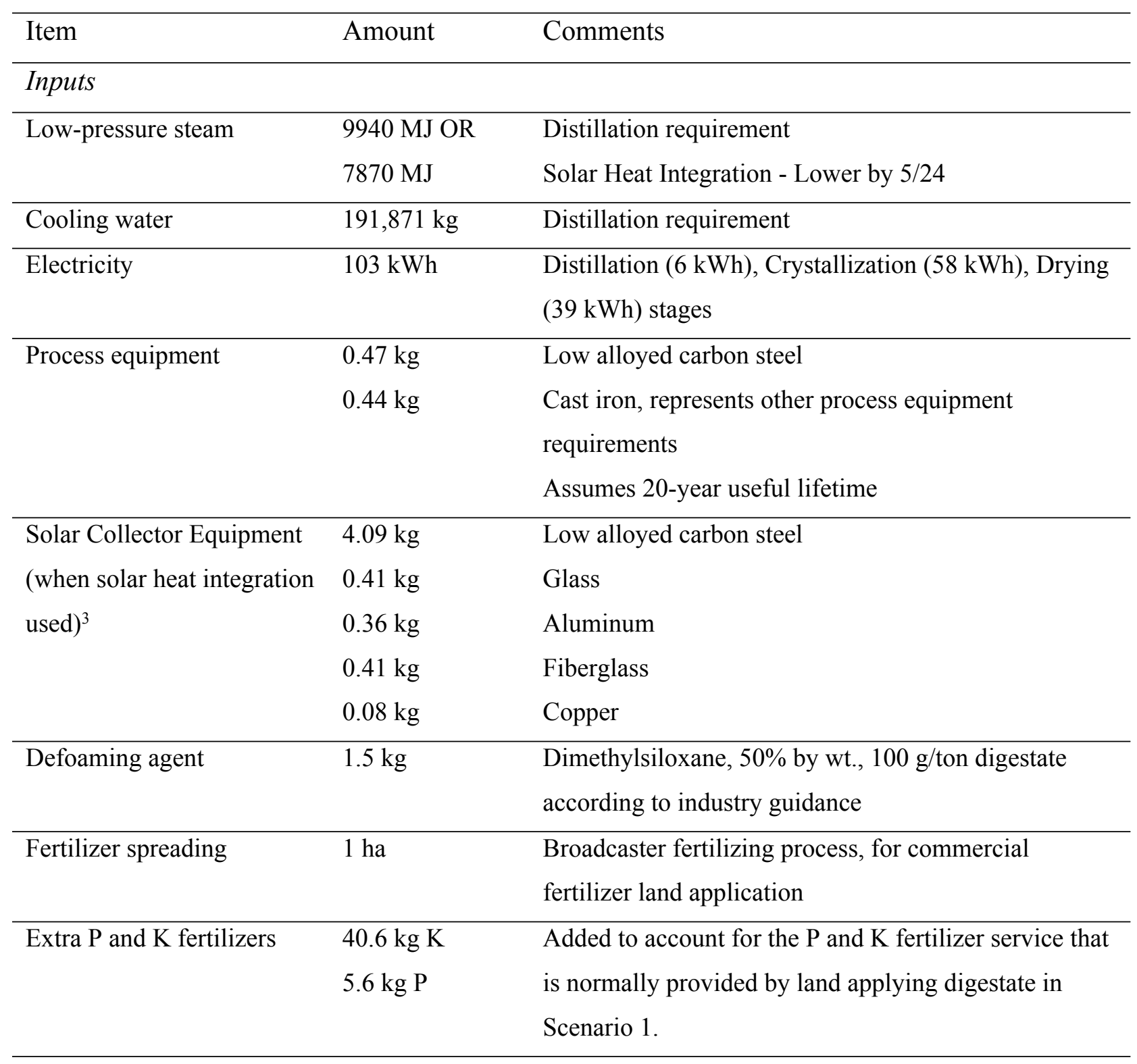


Key process outputs are shown below in Table S4. The choice of discharge location for the postprocess liquid digestate stream - to water, to land (farm field), or a wastewater treatment plant comes with different assumptions surrounding the fate of the organic $\mathrm{N}$ and $\mathrm{C}$ still retained within the liquid stream. These assumptions can be quite different. For instance, in Scenarios A and E, the TRACI environmental impact assessment method assumptions were used, which assume that organic-bound $\mathrm{C}$ and $\mathrm{N}$ do not convert to $\mathrm{CO}_{2}$ or $\mathrm{N}_{2} \mathrm{O}$ to influence global warming potential, nor does the organic $\mathrm{N}$ contribute to Eutrophication potential as calculated in the TRACI method. Therefore, Scenarios A and E represent a relatively low-impact set of assumptions. To illustrate the impacts of an assumption where some of the organic $\mathrm{C}$ and $\mathrm{N}$ is available to be metabolized and ultimately exert an environmental impact, a case of moderate impacts from C ( $5 \%$ bioavailable) and N (25\% bioavailable) was used for Scenarios B and F, adapting data from a study of dissolved $\mathrm{N}$ and $\mathrm{C}$ in rivers across the Eastern United States. ${ }^{4}$ For Scenarios C and G, a land application scenario was developed, which followed the same assumptions for $\mathrm{C}$ mineralization $\left(92 \%\right.$ converted to $\left.\mathrm{CO}_{2}\right)$ used in prior work for land application of digestate, ${ }^{5}$ IPCC Tier 1 assumptions for $\mathrm{N}_{2} \mathrm{O}$ emissions from the land application, ${ }^{6}$ and an assumption that $20 \%$ of organic N leaches and contributes to eutrophication as seen in Styles $e t$ $a l .{ }^{7}$ In Scenarios D and $\mathrm{H}$, the post-processed liquid digestate stream is assumed to be sent to a wastewater treatment plant (WWTP). An Ecoinvent WWTP profile for high-strength wastewater (sewage whey digestion) was adapted to better reflect the high TOC and total N values still present within the liquid stream, and impacts were based on this modified WWTP profile with values adjusted to reflect the TOC and $\mathrm{N}$ values for this post-process digestate stream. $\mathrm{CO}_{2}$ emissions resulting from the metabolism of organic $\mathrm{C}$ are higher than the water-discharge assumptions but lower than the land application scenario where it is assumed that $92 \%$ of the carbon is metabolized to $\mathrm{CO}_{2}$, which reflects the conditions that a significant portion of the carbon is retained in the biosolids within a typical WWTP. N release from the WWTP is still quite high, however, which is something that will warrant further consideration. 
Table S4 - Summary of key process outputs for LCA modeling

\begin{tabular}{|c|c|c|}
\hline Item & Amount & Comments \\
\hline Gas Purge Emissions & $77 \mathrm{~kg} \mathrm{CO}_{2} \mathrm{eq}$ & $\begin{array}{l}\text { During Distillation, other outputs include water, } \mathrm{N}_{2} \text {, trace } \\
\mathrm{NH}_{3}\end{array}$ \\
\hline $\begin{array}{l}\text { Inorganic } \mathrm{C} \\
\text { emissions }\end{array}$ & $\begin{array}{ll}94.7 & \mathrm{~kg} \\
\mathrm{CO}_{2} \mathrm{eq} & \end{array}$ & $\begin{array}{l}50 \% \mathrm{C} \text { in ammonium bicarbonate product sequestered, } \\
\text { rest is emitted as } \mathrm{CO}_{2}\left(86 \mathrm{~kg} \mathrm{CO} \mathrm{CO}_{2} \mathrm{eq} \text {, along with the }\right. \\
\text { balance of inorganic } \mathrm{C} \text { remaining after processing }\end{array}$ \\
\hline Organic $\mathrm{C}$ emissions & $\begin{array}{l}0 \mathrm{~kg} \mathrm{CO} \mathrm{eq}^{\mathrm{eq}} \\
61.5 \mathrm{~kg} \\
\mathrm{CO}_{2} \mathrm{eq} \\
1131 \mathrm{~kg} \\
\mathrm{CO}_{2} \mathrm{eq} \\
395 \mathrm{~kg} \\
\mathrm{CO} 2 \mathrm{eq}\end{array}$ & $\begin{array}{l}\text { Scenarios A and E - TRACI assigns no impact to org-C } \\
\text { Scenarios B and F - moderate bioavailability of org-C } \\
\text { Scenarios C and G - land application, assumes } 92 \% \\
\text { emitted as CO2 } \\
\text { Scenarios D and H - WWTP, based on Ecoinvent } \\
\text { database }\end{array}$ \\
\hline $\mathrm{N}_{2} \mathrm{O}$ emissions & $\begin{array}{l}0.95 \mathrm{~kg} \mathrm{~N}_{2} \mathrm{O} \\
1.19 \mathrm{~kg} \mathrm{~N}_{2} \mathrm{O}\end{array}$ & $\begin{array}{l}\text { All Scenarios - mineral fertilizer application of } \\
\mathrm{NH}_{4} \mathrm{HCO}_{3} \\
\text { Scenarios } \mathrm{C} \text { and } \mathrm{G} \text { land application of post-processed } \\
\text { digestate with residual org-N } \\
\text { IPCC Tier } 1 \text { assumptions for all } \mathrm{N}_{2} \mathrm{O} \text { release estimates }\end{array}$ \\
\hline $\mathrm{N}$ lost from leaching & $\begin{array}{l}5.48 \mathrm{~kg} \mathrm{~N} \\
0 \mathrm{~kg} \mathrm{~N} \\
8.6 \mathrm{~kg} \mathrm{~N} \\
6.9 \mathrm{~kg} \mathrm{~N} \\
19.9 \mathrm{~kg} \mathrm{~N}\end{array}$ & $\begin{array}{l}\text { All Scenarios - 10\% of commercial N fertilizers lost to } \\
\text { leaching } \\
\text { Scenarios A and E - TRACI assigns no impact to org-N } \\
\text { Scenarios B and F - moderate bioavailability of org-N } \\
\text { Scenarios C and G - land application, assumes } 20 \% \\
\text { leaching } \\
\text { Scenarios D and H - WWTP, based on Ecoinvent } \\
\text { database }\end{array}$ \\
\hline
\end{tabular}

Scenarios were modeled using the SimaPro life cycle assessment software, version 9, using the Ecoinvent version 3 database to characterize the full inventory data from the inputs listed above. Steam from a chemical industry eco profile and medium voltage electricity from the RFC U.S. 
electric grid subregion were used to represent utility requirements for heat and power, respectively. The TRACI method of calculating environmental impacts was used to perform the impact assessment. TRACI is a midpoint-focused model developed by the U.S. EPA and includes a range of impacts related to human and environmental health. ${ }^{8}$ In this study dealing with processes that involve significant $\mathrm{C}$ and $\mathrm{N}$ transformations and dynamics, the two environmental impacts of most interest are Global Warming Potential and Eutrophication, while we will report the impacts in other metrics as well. 
Table S5 - midpoint indicator LCA results from the TRACI impact assessment method

\begin{tabular}{|c|c|c|c|c|c|c|c|c|c|}
\hline Scenarios & Units & A & B & $\mathrm{C}$ & $\mathrm{D}$ & $\mathrm{E}$ & $\mathrm{F}$ & $\mathrm{G}$ & $\mathrm{H}$ \\
\hline $\begin{array}{l}\text { Ozone } \\
\text { depletion }\end{array}$ & kg CFC-11 eq & 0.00015 & 0.00015 & 0.00014 & 0.00031 & 0.00012 & 0.00012 & 0.00011 & 0.00028 \\
\hline $\begin{array}{l}\text { Global } \\
\text { warming }\end{array}$ & $\mathrm{kg} \mathrm{CO} 2$ eq & 1636.54 & 1698.04 & 3070.66 & 2080.24 & 1506.53 & 1568.03 & 2940.65 & 1950.23 \\
\hline Smog & $\mathrm{kg} \mathrm{O} 3 \mathrm{eq}$ & 40.72 & 40.72 & 37.11 & 112.38 & 39.77 & 39.77 & 36.16 & 111.42 \\
\hline Acidification & $\mathrm{kg} \mathrm{SO} 2 \mathrm{eq}$ & 4.44 & 4.44 & 4.04 & 12.02 & 4.36 & 4.36 & 3.96 & 11.93 \\
\hline Eutrophication & $\operatorname{kg~N~eq~}$ & 6.86 & 15.34 & 13.30 & 101.89 & 6.95 & 15.43 & 13.39 & 101.98 \\
\hline Carcinogenics & CTUh & 0.00002 & 0.00002 & 0.00002 & 0.00007 & 0.00003 & 0.00003 & 0.00002 & 0.00007 \\
\hline $\begin{array}{l}\text { Non- } \\
\text { carcinogenics }\end{array}$ & CTUh & 0.00017 & 0.00017 & 0.00012 & 0.00036 & 0.00019 & 0.00019 & 0.00015 & 0.00038 \\
\hline $\begin{array}{l}\text { Respiratory } \\
\text { effects }\end{array}$ & $\mathrm{kg}$ PM2.5 eq & 0.40 & 0.40 & 0.32 & 0.71 & 0.41 & 0.41 & 0.34 & 0.72 \\
\hline Ecotoxicity & CTUe & 814153.5 & 814153.5 & 813279.5 & 818186.7 & 814813.9 & 814813.9 & 813939.9 & 818847.1 \\
\hline $\begin{array}{l}\text { Fossil fuel } \\
\text { depletion }\end{array}$ & MJ surplus & 2091.34 & 2091.34 & 2004.82 & 2627.14 & 1930.01 & 1930.01 & 1843.48 & 2465.81 \\
\hline
\end{tabular}




\section{References}

(1) Tagle-Salazar, P. D.; Nigam, K. D. P.; Rivera-Solorio, C. I. Parabolic trough solar collectors: A general overview of technology, industrial applications, energy market, modeling, and standards. Green Process. Synth. 2020, 9 (1), 595-649, DOI: 10.1515/gps2020-0059.

(2) Turton, R.; Bailie, R. C.; Shaeiwitz, W. B. W. J. A.; Bhattacharyya, D. Analysis, Synthesis and Design of Chemical Processes, 4th ed.; Prentice Hall: New York, 2012.

(3) US DOE. Energy technology characterizations handbook: environmental pollution and control factors; Washington, D.C., 1983.

(4) Wiegner, T.; Seitzinger, S.; Glibert, P.; Bronk, D. Bioavailability of dissolved organic nitrogen and carbon from nine rivers in the eastern United States. Aquat. Microb. Ecol. 2006, 43 (3), 277-287, DOI: 10.3354/ame043277.

(5) Frank, E. D.; Han, J.; Palou-Rivera, I.; Elgowainy, A.; Wang, M. Q. Argonne National Laboratory. Life-Cycle Analysis of Algal Lipid Fuels with the GREET Model; Lemont, IL, 2011.

(6) Hergoualc'h, K.; Akiyama, H.; Chirinda, M.; Ngonidzashe, B.; Prado, A. del; Kasimir, Å.; MacDonald, J. D.; Ogle, S. M.; Regina, K.; Weerden, T. J. van der. 2019 Refinement to the 2006 IPCC Guidelines for National Greenhouse Gas Inventories: Chapter 11: N2O emissions from managed soild and CO2 emissions from lime and urea applications; 2019.

(7) Styles, D.; Adams, P.; Thelin, G.; Vaneeckhaute, C.; Chadwick, D.; Withers, P. J. A. Life Cycle Assessment of Biofertilizer Production and Use Compared with Conventional Liquid Digestate Management. Environ. Sci. Technol. 2018, 52 (13), 7468-7476, DOI: 10.1021/acs.est.8b01619.

(8) Bare, J. TRACI 2.0: the tool for the reduction and assessment of chemical and other environmental impacts 2.0. Clean Technol. Environ. Policy 2011, 13 (5), 687-696, DOI: 10.1007/s10098-010-0338-9. 